ECOLOGICA, Vol. 28, No 102 (2021), 315-324

https://doi.org/ 10.18485/ecologica.2021.28.102.25

Originalni naučni rad

UDC: $339.97[616.98: 578.834]$

$330.144 .2(616.98: 578.834]$

\title{
Uticaj Covid-19 na međunarodne ekonomske odnose i međunarodno kretanje kapitala
}

\section{Impact of Covid-19 on international economic relations and international capital movement}

\author{
Miloš Karajović ${ }^{1}$, prof. dr Milica Kaličanin ${ }^{2 *}$, prof. dr Zoran Kaličanin ${ }^{3}$ \\ ${ }^{1}$ m.s. ovlašćeni revizor, Nexia Star doo, Beograd, Srbija / m.s. certified auditor, Nexia Star Ilc, Belgrade, Serbia \\ ${ }^{2,3}$ Univerzitet Nikola Tesla, Beograd, Srbija / University Nikola Tesla, Belgrade, Serbia \\ *Autor za prepisku / Corresponding author
}

Rad primljen / Received: 16.12.2020, Rad prihvaćen / Accepted: 19.05.2021.

Sažetak: Ovaj rad ima za cilj da prikaže uticaj COVID-19 pandemije na dosadašnje uobičajene načine na koje se obavljaju međunarodna trgovanja i uspostavljaju međunarodni ekonomski i finansijski odnosi. Posledice koje ima pandemija na međunarodnu trgovinu imaju svoju kratkoročnu i dugoročnu komponentu i izrazito su nepredvidive. Nisu sve privredne delatnosti pogođene na isti način. Efekti na kretanja u privredama i na BDP se još uvek sagledavaju i pokušavaju se pronaći paralele sa nekim događajima iz prošlosti. Neke paradigme, poput globalizma, u koje se do nedavno čvrsto verovalo sada su osvetljene i sa druge strane i doživljavaju velika preispitivanja. Usled novih okolnosti, transakcije između povezanih privrednih društava, kao specifični oblici poslovanja stavljaju pred sebe nove izazove i modele saradnje, tako da će i izveštavanje o transfernim cenama pretrpeti značajna prilagođavanja u odnosu na dosadašnju praksu, jer da obezbedi kvalitetnu i validnu osnovu za zaključivanje o ispunjenosti principa „van dohvata ruke“. Takođe, dosadašnje determinante međunarodnog kretanja kapitala doživljavaju značajne izmene i pojavljuju se novi motivi koji utiču na prekogranično investiranje.

Ključne reči: pandemija, lanci snabdevanja, međunarodna trgovina, ekonomski odnosi, nacionalna ekonomija, OECD smernice..

\begin{abstract}
This paper aims to show the impact of the COVID-19 pandemic on the usual common ways in which international trade is conducted and international economic and financial relations are established. The consequences of a pandemic on international trade have short-term and long-term components and they are extremely unpredictable. Not all economic activities are affected in the same way. The effects on economic developments and on GDP are still being considered and attempts are being made to find parallels with some events from the past. Some paradigms, such as globalism, which until recently were firmly believed, are now illuminated on the other side and are undergoing significant re-examination. Due to new circumstances, transactions between related parties, as specific forms of business, are in front of new challenges and models of cooperation, so the reporting of transfer pricing will suffer significant adjustments compared to previous practice, because it should provide a quality and valid basis for concluding fulfillment of the "out of arm's length" principle. Also, the current determinants of international capital movements are experiencing significant changes there are new motives that cause cross-border investments.
\end{abstract}

Keywords: pandemic, supply chains, international trade, economic relations, national economy, OECD guidelines.

\footnotetext{
${ }^{1}$ orcid.org/0000-0001-5917-0045, e-mail: milos.karajovic@gmail.com

${ }^{2}$ orcid.org/0000-0002-4770-7631, e-mail: milica.kalicanin@fpsp.edu.rs

3orcid.org/0000-0002-9569-7175, e-mail: zoran.kalicanin@fpsp.edu.rs
} 


\section{UVOD / INTRODUCTION}

Kod svake nacionalne privrede postoji nužnost stupanja u komercijalne i finansijske odnose sa drugim državama na svetskom tržištu. U ovim odnosima najčešće razlikujemo tri vrste transakcija:

- uvoz i izvoz robe i usluga,

- uvoz i izvoz kapitala i

- jednostrane transfere.

Na međunarodnom tržištu robe i kapitala se javljaju mnoge specifičnosti u odnosu na pojedinačna nacionalna tržišta u pogledu načina poslovanja, institucionalne strukture, načina formiranja kamatnih stopa, tokova sredstava između kreditora i dužnika i slično.

Epidemija COVID-19 iznenadila je svet i u značajnoj meri poremetila dosadašnji uobičajeni način funkcionisanja međunarodnog tržišta i odnosa između nacionalnih ekonomija brišući po neke od do juče najznačajnijih postulata za koje su se neke zemlje zalagale, a u novim uslovima potpuno odustaju od njih i kritički in krše. $U$ početku se na pandemiju gledalo kao na Kineski, a kasnije i jugoistočni Azijski problem. Međutim, zbog kombinacije različitih faktora prirodnih, političkih i regulatornih karaktera, epidemija se brzo proširila na druge delove sveta i brzo postala priznata od Svetske zdravstvene organizacije kao pandemija. Postojeća međusobna povezanost među zemljama očigledno je olakšala to širenje. U početku se na pandemiju pretežno gledalo kao na problem javnog zdravlja. Međutim kako je vreme prolazilo uočen je uticaj na ukupan život, pa time i na ekonomiju i na uspostavljanje potpuno drugačijih naglo uspostavljenih međunarodnih ekonomskih i finansijskih odnosa.

Značajan broj ekonomskih stručnjaka i međunarodnih institucija prati i predviđa uticaj pandemije na globalnu ekonomiju i sada već uobičajeno čujemo frazu "globalna recesija“.

U ovom kontekstu, neki stručnjaci, na primer, brinu o budućnosti evropskih integracija, ukazujući na neadekvatan odgovor evropskih institucija. Drugi vide pandemiju COVID-19 kao egzistencijalnu pretnju liberalnoj demokratiji i liberalnoj ekonomiji.

Pandemija COVID-19 izazvala je značajne izmene u našim životima, a svakako i postavila značajan ekonomski izazov pred poslovanje privrednih društava. Pateći trendove proučavanja uticaja pandemije, Privredna komora Srbije i USAID-ov Projekat saradnje za ekonomski razvoj sprovode anketu „Zajedno kroz krizu“ koja je posvećena ekonomskim aspektima krize i uticaju koji ona ima na privredu i poslovanje. Dosadašnji rezultati pokazuju da se kompanije u privatnom sektoru u Srbiji najčešće suočavaju sa sposobnošću pokrića osnovnih troškova poslovanja, odlaganjem i otkazivanjem porudžbina, smanjenim prihodima kao i problemima sa likvidnošću. Takođe, kao moderan izazov pred kompanije se postavlja mogućnost prilagođavanja poslovanju preko interneta.

Uočljivo je da nisu svi sektori pogođeni pandemijom na isti način. Građevinarstvo beleži značajan pad, finansira se često iz kredita na koje kamate nastavljaju da teku, a nije moguće organizovati rad od kuće i neophodni su novi načini organizovanja rada kako bi se obezbedila sigurnost radnika na izgradnji. Osiguranje je više izloženo riziku aktivacije polisa životnog osiguranja zbog rasta smrtnosti stanovništva. Transportne delatnosti su jedne od najugroženijih, jer je smanjen obim aktivnosti i putovanja privatnih lica sa jedne strane i potpuno izmenjeni lanci snabdevanja, sa druge. Turizam i ugostiteljstvo, zbog ograničenog kretanja stanovništva beleže značajan pad poslovanja ili čak obustavljanje delovanja u pojedinim trenucima. Jedna od retkih oblasti koje imaju pozitivan uticaj pandemije na svoje poslovanje je proizvodnja lekova i zaštitne opreme čiji su prihodi uvećani u ovom periodu.

Izmene u poslovanju i opštoj privrednoj klimi, imaju jak uticaj i na prirodu transakcija koje se u novim okolnostima dešavaju između povezanih lica. Time se, pred nas se postavlja izazov u tumačenju tržišnog karaktera transakcija između povezanih lica i načinu na koji u novoj atmosferi treba primeniti metode koje se po principu „van dohvata ruke“ primenjuju kod utvrđivanja cene transakcija među povezanim licima (Pravilnik o transfernim cenama, 2019).

\section{MATERIJALI I METODE / MATERIALS AND METHODS}

Međunarodna ekonomija kao praktična potreba i naučna disciplina se kroz istoriju razvijaju, prateći zahteve privrede, javnosti, fiskusa i u prvoj meri onih koji upravljaju privrednim subjektima i onih koji su vlasnici kapitala. Tako da sistemi za praćenje uspešnosti i komparacije tržišta na internacionalnom nivou postaju sve sofisticiraniji i korisniji. Značajan doprinos temi daju multinacionalne kompanije i međunarodne organizacije čije preporuke imaju

Cilj ovog rada je da ukaže na posledice koje pandemija COVIID-19 ostavlja na međunarodnu ekonomsku saradnju, razmenu i aspekte tih posledica. Neke od posledica su kratkog ili dugog roka, dok su neke trajne ili jednokratne. Na uticaj pandemije su različito reagovale različite privredne delatnosti, kao i pojedini entiteti $u$ istoj grani delatnosti. Takođe, pruženi su argumenti „pro et kontra“ globalizacije i regionalizacije i novi pogledi na njih u novim okolnostima.

Do sada, postoji jako mali broj objavljenih domaćih i stranih radova na ovu temu. Kao glavni izvor podataka iznetih u ovom radu su istraživanja koja su sprovele međunarodne organizacije poput OECD, WTO kao i lokalna privredna komora u saradnji sa USAID. Takođe, istraživanja su sprovedena i u 
tekućem poslovanju kojim se bave autori, po prirodi posla upućeni na saradnju sa inostranim entitetima.

Ovaj rad predstavlja kratak osvrt na uticaj prirodnih promena na međunarodnu ekonomsku saradnju, postulate na kojima se ona zasniva i njihovo preispitivanje. Društveni značaj je ukazivanje da nije moguće lako utvrditi paralele sa istorijskim događajima i pokušaj da se ukaže na sve izazove savremenog poslovanja na međunarodnom tržištu.

\section{REZULTATI I DISKUSIJA / RESULTS AND DISCUSSION}

\subsection{Uticaj na različite privredne delatnosti i lance} snabdevanja /

Impact on various economic activities and supply chains

Najnovije procene OECD-a od 10. juna predvidele su kolaps bez presedana u prvoj polovini 2020. godine - pad globalnog BDP-a od skoro 13\%. Ovo je značajno gori scenario od onoga koji je objavljen u martu gde globalni privredni rast iznosi 1,5\%. Takođe, troškovi globalne ekonomije učinjeni za ublažavanje posledica pandemije od paketa podrške, preko centralnih banaka i fiskalnih akcija, veoma su značajni i verovatno će imati dugotrajne i složene efekte na upravljanje državnim i korporativnim dugovima. Uprkos naporima i značajnim resursima uloženim u prevazilaženje krize, većina glavnih ekonomija će ući u recesiju.

Svaki sektor privrede pogođen je na specifičan način i suočava se sa sopstvenim problemima. Naravno, postoje i oni sektori koji u uslovima pandemije doživljavaju povećanje obima poslovanja.

Eurostat je objavio publikaciju u kojoj je prezentovano kretanje industrijske proizvodnje u 2020. godini u 27 zemalja Evropske unije, gde je očigledan značajan pad u aprilu mesecu:

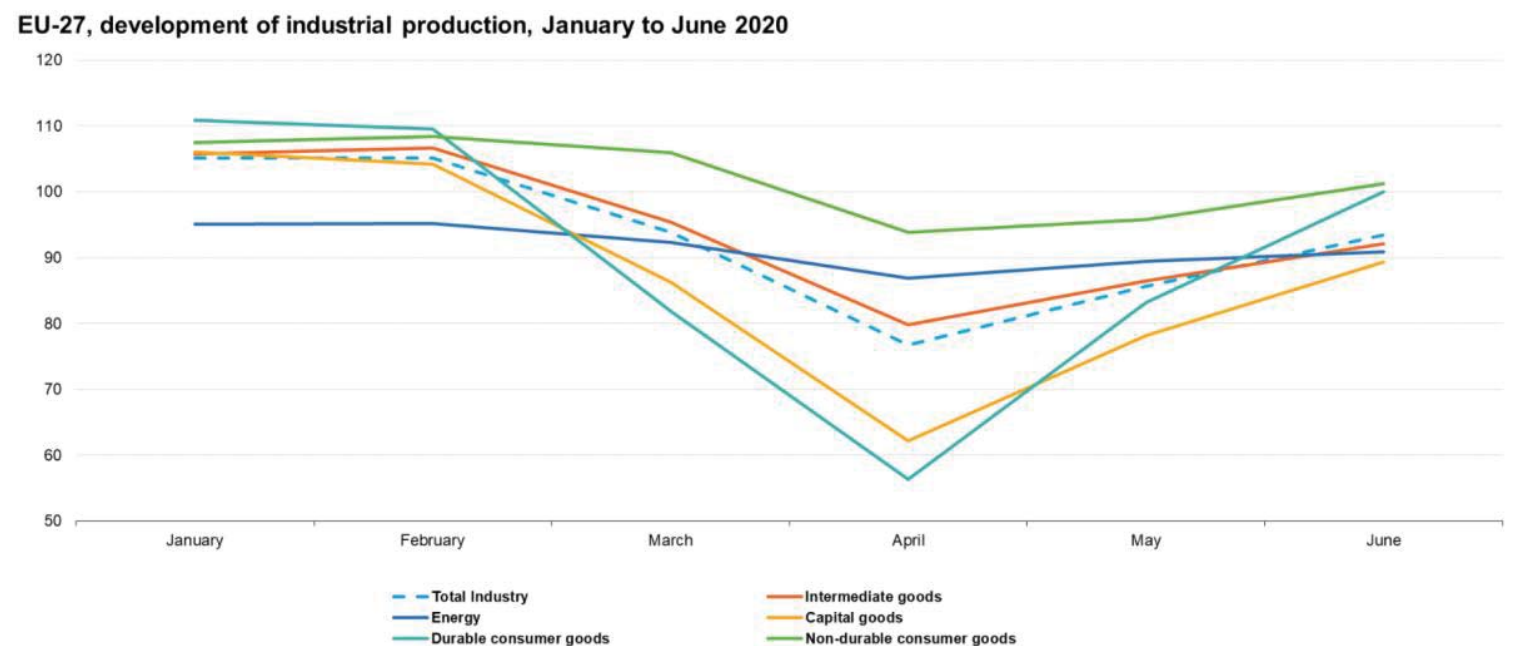

Source: Eurostat (online data code: sts_inpr_m)

eurostat 요

Grafikon 1 - EU-27, Razvoj industrijske proizvodnje od januara do juna 2020

Graph 1 - EU-27, Development of industrial production from January to June 2020

Dalji izazov je neizvesnost u vezi sa COVID-19, uključujući i obim i tempo infekcije; koliko dugo i široko rasprostranjene mere će se pokazati neophodnim; izgledi za izlečenje koje omogućavaju zdravstvenim službama da se fokusiraju samo na najozbiljnije slučajeve; i rizik od „drugog talasa“ dok se virus kreće širom sveta. Virus se odvija u talasima, a zemlje podležu - i treba da se oporave u različito vreme. Jasno je da je verovatno da će virus i njegove posledice biti sa nama neko vreme (Gruszczynski, 2021).

U zdravstvenim kontekstu odnosno neizvesnosti u vezi sa COVID-19 uključujući obim i tempo širenja epidemije, postoji jasna potreba za kontinuiranim održavanjem trgovine kako da se obezbedilo snab- devanje osnovnim proizvodima. Trgovina postaje suštinski značajna za održavanje i života i sredstava za život.

Održavanje dovoljnog volumena trgovine zahteva saradnju i poverenje između država, na primer, da države neće nametati izvozna ograničenja i da uvoz ne predstavlja zdravstveni rizik. Ovo je poseban izazov u vreme trgovinskih tenzija, gde je međunarodni sistem trgovine već bio podložan povećanom broju novih ograničenja, od povećanja carina među glavnim trgovcima, do značajne vladine podrške u ključnim sektorima.

Uprkos znatnoj neizvesnosti OECD upućuje da postoje četiri akcije koje se sada mogu preduzeti: 
- pojačano poverenje u trgovinu i globalno tržište poboljšavanjem transparentnosti,

- održavanje globalnih lanaca snabdevanja, posebno osnovnim namirnicama,

- izbegavanje da stvari postanu još gore,

- političke akcije.

Od presudnog značaja je da države ispoštuju svoje obaveze da obaveštavaju o trgovinskim merama koje su preduzete kao odgovor na COVID-19 i da blagovremeno izveste Svetsku trgovinsku organizaciju (STO).

Važan prioritet je održavanje ključnih lanaca snabdevanja neophodnim robama za krizu, uključujući medicinske potrepštine i prehrambene proizvode, otvorenim i funkcionalnim. Ispunjenje ove mere u značajnoj meri usporavaju različiti izazovi:

Otkazivanje putničkih letova povezano sa zabranom putovanja ograničilo je dostupnost vazduš- nog transporta tereta (slika 1), što je rezultiralo rastom cena vazdušnog transporta tereta.

Važne brodske luke prijavile su međugodišnji pad prometa teretom između $10 \%$ i $20 \%$, a preko 50 zemalja je promenilo lučke protokole, od zatvaranja luka i mera karantina do dodatnih zahteva za dokumentacijom i pregledima. Veliki broj brodskih kontejnera nalazio se u kineskim lukama, a ograničenja njihovog kretanja dovela su do nestašice zbog koje je cena kontejnera rasla (u nekim slučajevima znatno).

Ograničenja na polju kretanja ljudi i zaključavanja utiču na niz trgovinskih procesa, od fizičkih pregleda robe, preko ispitivanja i sertifikata, do promene načina na koji se sprovode antidampinške istrage.

Sve ovo povećava vreme i troškove međunarodne trgovine (Jovanović Gavrilović, 2010).

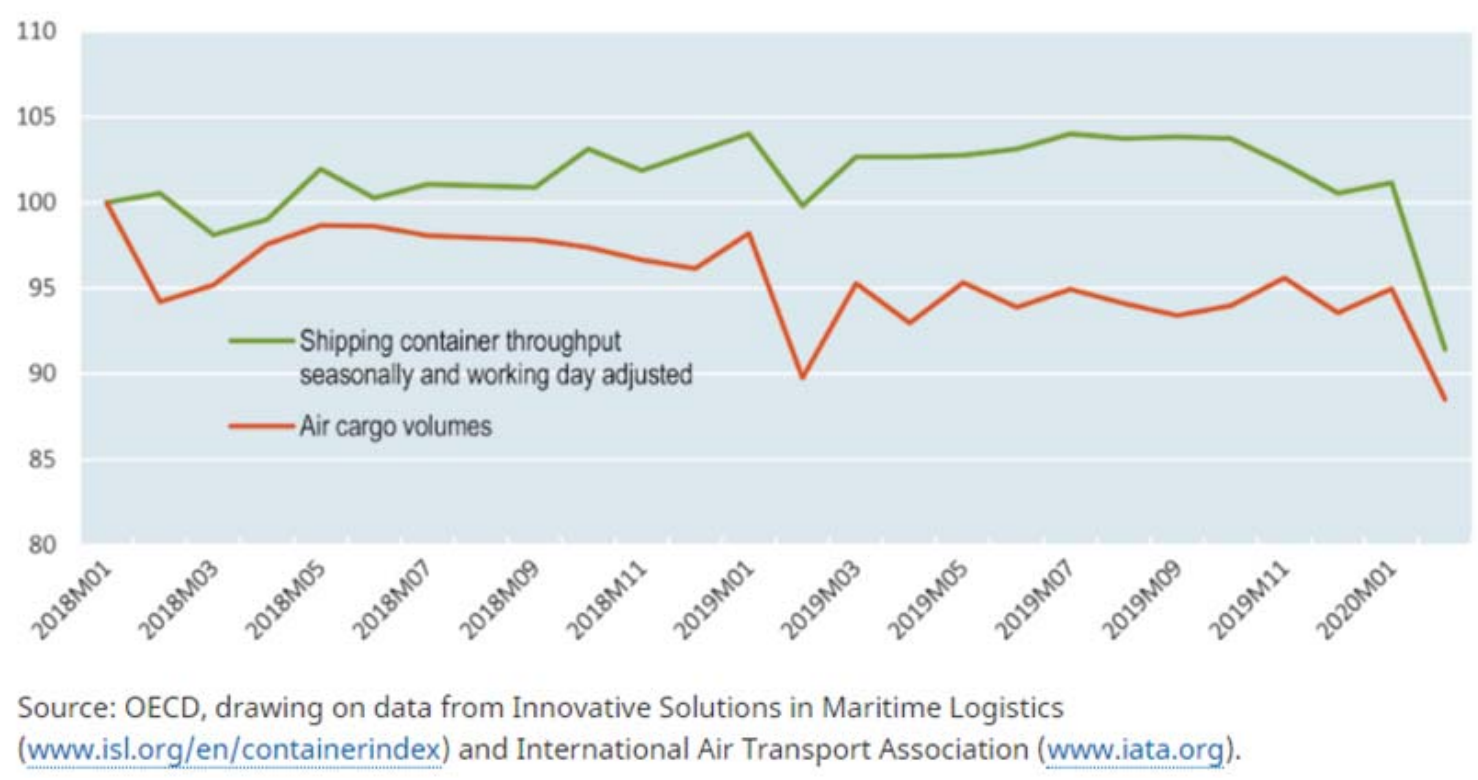

Slika 1 - Oštar pad morskog i avionskog transporta / Figure 2 - Sharp dropdown of sea and air transport

Postoje izraženi problemi sa održavanjem lanaca snabdevanja hranom. Pored uticaja smanjenih mogućnosti vazdušnog i pomorskog transporta tereta, dodatni su izazovi povezani sa rizikom od otpada usled odlaganja i poteškoća sa rukovanjem i naglog pada potražnje iz restorana i hotela.

$U$ trenutnoj pandemiji ima mnogo neizbežnih troškova što ukazuje na više razloga za izbegavanje radnji koje trgovcima i potrošačima povećavaju troškove. Među njima je glavna potreba da se izbegnu ograničenja izvoza osnovnih proizvoda, poput medicinske opreme $i$, posebno, prehrambenih proizvoda. Trenutno je više od 60 zemalja ograničilo izvoz osnovnih proizvoda i sve više poljoprivrednih i prehrambenih proizvoda. (Evenett, 2020). lako su države danas nužno usredsređene na osiguravanje zdravstvene i ekonomske sigurnosti svog naroda, OECD se pojavljuje kao važan faktor koji objedinjuje, analizira i objavljuje podatke pokušavajući da pruži što više podataka koji treba da obezbede široko rasprostranjen oporavak (Smernice OECD, 2011).

\subsection{Pozitivan uticaj na nove oblike trgovine / \\ Positive impact on new forms of trade}

Zbog opasnosti od korona virusa prodavnice i tržni centri su naredbom pojedinih Vlada zatvoreni ili je izvršeno značajnije ograničenje radnog vremena ili broja kupaca u objektu. Značajan obim trgovine se preselio na internet (Vassileva et al., 2020). 
U nekim državama, oniline prodaja je bila skoro zanemarljiva, ali sada pored naručivanja preko interneta iz dalekih zemalja, što je bio najčešći slučaj sa poznatim reprezentativnim platformama iz Kine, kupci na internetu postaju građani zemalja iz kojih su i trgovci.

Naravno, ono što je bilo za očekivati u ovakvim uslovima je da postoji značajan rast u proizvodnji i trgovini zaštitnom medicinskom opremom kao i lekovima koji se koriste u lečenju bolesti.

\subsection{Uticaj pandemije na ideju globalizma /} The impact of the pandemic on the idea of globalism

Globalizacija je, činilo nam se do skora, predstavljala zakonitost i potrebu i kao takva je prezentovana poslednjih decenija. Suština globalizacije je u razmerama i brzini međunarodnog poslovanja, koji su eksplodirali do neslućenih visina.

Olakšano kretanje kapitala, robe i usluga, internet, trgovinski sporazumi i brz rast ekonomija, zajedno čine sistem koji mnogo više zavisi od toga šta se dešava na drugom kraju sveta nego ikada pre.

Prema istraživanjima Evropske banke za obnovu i razvoj u odnosu na poslednju epidemiju iz 2013. godine (Sars virus) došlo je do značajnih promena na polju međunarodnih odnosa. Naime, tada je Kineska privreda predstavljala $4 \%$ globalne proizvodnje dok je sada taj udeo učetvorostručen na $16 \%$. Ova činjenica ukazuje da na ukupan svet ima uticaj promena u poslovnoj aktivnosti te države. Tako da je sada ljudima u svetu i privredi jako važno zdravlje čak i u nekima dalekoj Kini.

Sa druge strane, profesor Ričard Poters sa Londonske poslovne škole želi da ukaže da je dosadašnja globalistička praksa izvor značajnih rizika koji su do sada preuzimani i da će sada kada su jednom prekinuti lanci snabdevanja privredni subjekti pronaći alternativne dobavljače iz svoje zemlje čak i onda kada su njihove usluge skuplje.

Pravo pitanje, vezano za globalizam izgleda da nije da li će se promene desiti, već koliko će dalekosežne biti i kako će se one rešiti.

\subsection{Kratkoročne i dugoročne posledice / Short-term and long-term consequences \\ Efekti na kratak rok}

Izbijanje pandemije COVID-19 već je prouzrokovalo duboke poremećaje u svetskoj trgovini kako na strani ponude tako i na strani potražnje na nivou globalne ekonomije. Mnoge vlade su naredile privremeno zatvaranje proizvodnih pogona koji nisu značajni za osnovno funkcionisanje društva, iako su mnogobrojne korporacije preduzele takve mere dobrovoljno (npr. zbog deficita u ponudi radne snage) ili su jednostavno smanjile proizvodnju usled poremećaja u njihovim lancima snabdevanja. Uticaj pandemije je, međutim, najvidljiviji u sektoru međunarodnih usluga. Glavne žrtve su međunarodni turizam, putnički avionski prevoz, putnička i kontejnerska špedicija. Globalne finansijske transakcije kao i informacije i usluge komunikacione tehnologije takođe su značajno smanjene (Kaličanin, Perić, 2020). Neka predviđanja govore da će pandemija prouzrokovati smanjenje globalnih stranih investicija za $5 \%$ do $15 \%$ u 2020 . godini.

Potrošnja je takođe pogođena širom sveta. Ovaj fenomen može se pripisati uobičajenom strahu od gubitka prihoda (npr. zbog nezaposlenosti) i povećanoj neizvesnosti. Sve u svemu, može se očekivati kontinuirani pad obima međunarodne trgovine na kratak rok. Obim ovog opadanja je teško predvideti.

Bilo bi pogrešno misliti da je trenutna epidemiološka situacija rezultirala samo talasom trgovinskih ograničenja. Slika je mnogo složenija. Cilj svih ovih mera je da se obezbedi dovoljno snabdevanja na domaćim tržištima (bilo smanjenjem izvoza ili povećanjem uvoza).

Pandemija je takođe usporila napredak različitih međunarodnih odnosa i inicijativa širom sveta, jer su države trenutno zaokupljene krizom. Dobar primer je novi sporazum između SAD-a, Meksika i Kanade (takozvani USMCA) koji bi trebalo da zameni trenutni NAFTA aranžman. lako su ga već ratifikovale sve tri strane, njegovo stupanje na snagu zavisi od uspešnog sprovođenja obaveza na nacionalnom nivou. Dok je početni plan za sprovođenje sporazuma bio predviđen za 1 . jun 2020. godine, ovaj datum pokretanja je sada neodrživ.

Sa sličnim problemima mogu se suočiti i završeni razgovori između Velike Britanije i Evropske unije koji su zastali. Prema sporazumu o povlačenju, prelazni period za UK završava se 31. decembra 2020. Ako se ne postigne dogovor, međusobni trgovinski odnosi regulisaće se pravilima STO, pa se može očekivati videti (verovatno relativno brzo) produženje roka.

\section{Dugoročne posledice pandemije}

Globalna ekonomija izgrađena je na specijalizaciji radne snage u svim zemljama. U skladu sa teorijom komparativnih prednosti koja daje osnovu za trenutni sistem međunarodne razmene dobara i usluga, takva specijalizacija omogućava maksimizaciju ukupne proizvodnje i poboljšanje blagostanja. Pandemija je, međutim, pokazala da očigledne koristi sistema nose i značajne rizike. Paralela u mikroekonomiji bi bila izloženost rizikom prema jednom ili malom broju kupaca ili dobavljača, tzv. „risk exposure“. Sada "dobavljači sa jednim proizvodom ili 
uslugom ili regioni sveta koji su specijalizovani za jedan određeni proizvod, mogu stvoriti neočekivanu krhkost u trenucima krize, uzrokujući pucanje lanaca snabdevanja“" (Farrell, Newman, 2020).

Ovakvi značajni poremećaji imaju uticaj kako na pojedinačne kompanije, tako i na globalne sisteme distribucije. Sa stanovišta korporacija može se očekivati nov model za skraćivanje i diversifikaciju lanaca snabdevanja koji bi omogućio racionalnu strategija koja omogućava da se osigura nesmetano poslovanje i eliminiše rizik od nestašice u snabdevanju. Za vlade ovo može biti inicijator da ograniče zavisnost od jedne zemlje (posebno u vanrednim situacijama) i kao posledica toga da budu bolje pripremljene za buduće krize.

Pitanje koje se nameće na makro nivou jeste da li će novonastale okolnosti dovesti do uspostavljanja nacionalnih država ili do segmentacije sveta koja će se zasnivati na regionalnim ekonomskim blokovima. $\mathrm{Na}$ mikro nivou, odnosno na nivou privrednih subjekata, ove okolnosti moraju biti uzete u obzir prilikom sastavljanja novih operativnih budžeta i izmena postojećih dugoročnih planova, strategija i načina implementacije (Karajović et al., 2020a).

\subsection{Posledice u Srbiji / Consequences in Serbia}

Sve okolnosti i negativni efekti koji su navedeni na svetskom nivou nisu zaobišli ni naše područje. U nekim segmentima je sigurno $i$ još jače pogođena domaća krhka privreda.

Srpska ekonomija je u 2019. ostvarila rast od $4,2 \%$, ali sada joj preti recesija uzrokovana COVID19. Glavni faktori rasta su bili usluge, sa povećanjem od $4,2 \%$ i građevinarstvo sa povećanjem od $30,2 \%$, dok je prerađivačka industrija bila lošija.

Zbog pandemije ekonomija Srbije će u 2020. ući u recesiju. U prvoj polovini marta je 168 privrednih subjekata privremeno zatvoreno i skoro 5 procenata od ukupnog broja zaposlenih je radilo od kuće. Poremećaj ekonomskih aktivnosti je najistaknutiji u transportu i turizmu. Na osnovu vladinih procena, transportni sektor je od početka krize ostvario značajan gubitak, a dolazak turista i rezervacije su drastično smanjeni (Munitlak Ivanović, Vujić, 2021).

Po osnovnom scenariju BDP Srbije će se u 2020. smanjiti za 2,5 procenta. Osnovni scenario podrazumeva usporavanje zaraze korona virusom u Evropi tako da se mere suzbijanja mogu u potpunosti ukinuti.

Uticaj na ekonomiju će varirati po sektorima. Najviše će biti pogođena prerađivačka industrija, sa padom od oko $9 \%$. I usluge će biti snažno pogođene, ali u različitom stepenu; transport i turizam će biti najteže pogođeni, jer pojačanom aktivnošću u drugoj polovni godine neće moći da kompenzuje gubitke iz prve polovine. Stoga se projektuje pad usluga od $1 \%$ u 2020. Poljoprivreda bi mogla zabeležiti malo povećanje u 2020. Fiskalni deficit bi mogao dostići 7,3\% BDP-a, s obzirom da se očekuje pad prihoda od oko 3,3\%. Javni dug bi do kraja godine mogao dostići 63,9\% BDP-a.

Prikaz navedenog je kako sledi:

\begin{tabular}{|l|c|c|c|}
\hline & $\begin{array}{c}\text { Prvobitne } \\
\text { projekcije }\end{array}$ & $\begin{array}{c}\text { Novi } \\
\text { scenario }\end{array}$ & $\begin{array}{c}\text { Nepovoljni } \\
\text { scenario }\end{array}$ \\
\hline Realni rast BDP & 3,9 & $-2,5$ & $-5,3$ \\
\hline Potrošnja & 5,7 & $-2,3$ & $-3,5$ \\
\hline Investicije & 5,3 & $-5,2$ & $-7,7$ \\
\hline Izvoz & 4,9 & $-10,2$ & $-18,5$ \\
\hline Uvoz & 7,6 & $-9,7$ & $-15,1$ \\
\hline
\end{tabular}

Izvor: procena Svetske Banke/

Source: assesment of World Bank

\subsection{Statistike i znaci oporavka / \\ Statistics and signs of recovery}

Svetska trgovinska organizacija predviđa pad obima svetske trgovine robom za $9,2 \%$ za 2020 . godinu, praćen rastom od $7,2 \% 2021$. godine. Ove procene podležu neobično visokom stepenu nesigurnosti, jer zavise od razvoja pandemije i vladinih odgovora na nju.

Snažne trgovinske performanse $u$ junu i julu donele su neke znake optimizma za ukupan rast trgovine u 2020. godini. Rast trgovine proizvodima povezanim sa COVID-19 bio je posebno snažan u ovim mesecima, pokazujući sposobnost trgovine da pomogne vladama da nabave potrebne zalihe. Suprotno tome, prognoza za sledeću godinu pesimističnija je, što ostavlja trgovinu robom znatno ispod svog predpandemijskog trenda 2021. godine.

Za razliku od trgovine, BDP je pao više nego što se očekivalo u prvoj polovini 2020. godine, što je prouzrokovalo smanjenje prognoza za godinu.

lako je pad trgovine tokom pandemije COVID19 po veličini sličan globalnoj finansijskoj krizi 200809, ekonomski kontekst je veoma različit. Promena u vrednosti BDP-a je mnogo veća u trenutnoj recesiji, dok je pad trgovine umereniji. Kao rezultat toga, očekuje se da će obim svetske trgovine robom opadati dvostruko više od svetskog BDP-a po tržišnim kursevima, umesto šest puta više tokom kolapsa 2009. godine.

Ova divergentna trgovina u toku izbijanja COVID-19 ima mnogo veze sa prirodom pandemije i politikama koje se koriste za borbu protiv nje. Zaključavanja i ograničenja putovanja nametnula su značajna ograničenja na strani ponude nacionalnim ekonomijama, drastično smanjujući proizvodnju i zaposlenost u sektorima koji su obično otporni na 
oscilacije poslovnog ciklusa, posebno u uslugama (Živković et al., 2021).

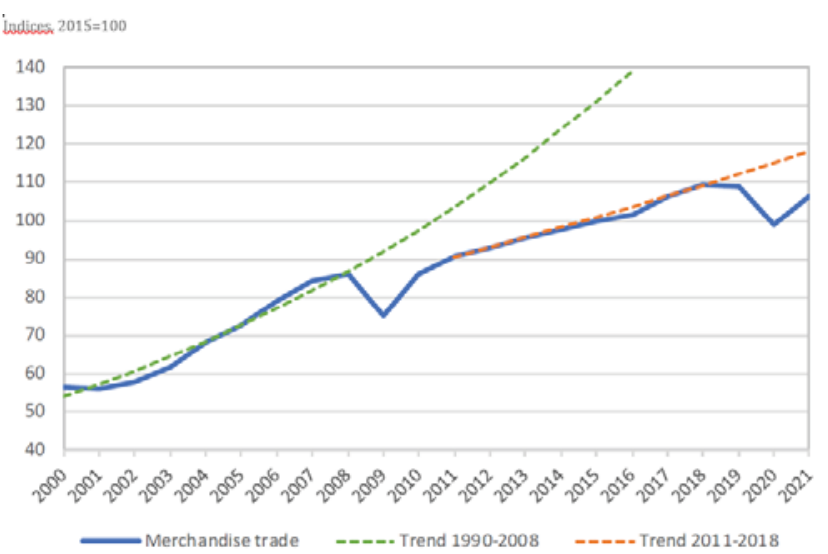

Slika 2 - Kretanje trgovine robom, Izvor sekretarijat STO, napomena; podaci za 2020. i 2021. su projekcije

Figure 2 - Movements of goods trade, Source: secretary of WTO, note: data for 2020 and 2021 are projections

Pad trgovine uslugama tokom pandemije bio je najmanje jednako jak kao pad trgovine robom. Ne postoje sveobuhvatne statistike o obimu trgovine uslugama zbog opšte nedostupnosti podataka o cenama, ali približna mera obima trgovine uslugama može se dobiti prilagođavanjem nominalne statistike trgovine komercijalnim uslugama kako bi se uzeli u obzir devizni kurs i inflacija. To ilustruje Slika 3 koja pokazuje mnogo strmiji međugodišnji pad globalne trgovine uslugama tokom trenutne recesije $(-23 \%$, od vrha do najnižeg nivoa) nego tokom finansijske krize $(9 \%)$. Pad je pogoršan ograničenjima na međunarodna putovanja, koja predstavljaju ključni izvor zarade od izvoza za mnoge zemlje sa niskim prihodima (Šiljak et al., 2021).

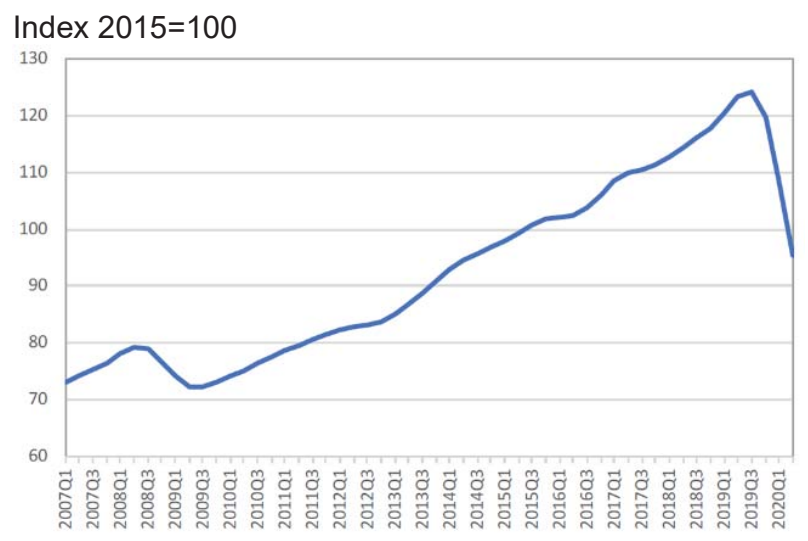

Slika 3 - Kretanje trgovine uslugama Izvor sekretarijat WTO

Figure 3 - Movements in service providing Source: secretary of WTO
2.7. Uticaj na transakcije između povezanih lica $i$ izveštavanje o transfernim cenama / Impact on related party transactions and transfer pricing reporting

Dosadašnja istraživanjima ukazuju na to da se najznačajnije izmene koje se mogu očekivati u domenu uticaja COVID-19 na transferne cene u transakcijama između povezanih lica odnose na:

1) Postojeće politike transfernih cena grupe povezanih lica,

2) Metode za dokazivanje transfernih cena i

3) Finansijsku podršku između povezanih lica.

Politike transfernih cena

Grupe povezanih lica koje su najčešće međunarodnog karaktera ustanovljavaju svoje politike transfernih cena. Ove politike su pod naročitom pažnjom poreskih vlasti koje treba da procena da li su transakcije koje su se odigrale između povezanih lica neuobičajene, da li su sprovedene sa ciljem poreske optimizacije grupe povezanih pravnih lica ili je u tim transakcijama nastala okolnost u kojoj je neka država imala manji priliv po osnovu poreza na dobit usled poslovanja ovih grupa povezanih lica, odnosno da je neka od kompanija iskazala manji profit od tržišnog usled transfernih cena koje su se odigravala po pravilima koja nisu u skladu sa principom „van dohvata ruke“. U okolnostima koje je nametnula pandemija, postojaće pritisci za izmene ustanovljenih politika transfernih cena, naročito ukoliko u okviru grupe neki od entiteta bude iskazao smanjenu profitabilnost ili negativan rezultat poslovanja. Nov način poslovanja će nam pokazati da ukoliko analiziramo istu privrednu granu, mogu postojati poslovni subjekti koje je pandemija značajnije ili manje značajno pogodila. Vidimo da distributeri sa izraženom diversifikacijom svog portfolija mogu pretrpeti manji udar nego oni koji prodaju samo artikle koji su značajnije pogođeni globalnim padom tražnje, pa time i prometa. Pojaviće se značajni stručni izazovi kada poslovne rezultate koji su ispod uobičajenih treba opravdati odnosno dokazati da su nastali zbog uticaja COVID-19, a ne zbog transakcija sa povezanim licima koje su se odigrale pod uslovima koji su manje povoljni od tržišnih.

Metode za dokazivanje transfernih cena

Način na koji će se dokazivati transferne cene proizilazi iz funkcionalne analize transakcije između povezanih lica i analize uporedivosti kao srži izveštaja o transfernim cenama (Karajović et al., 2020b). Članom 10 Pravilnika o transfernim cenama i metodama koje se po principu „van dohvata ruke“ primenjuju kod utvrđivanja cene transakcija među pove- 
zanim licima je definisano da se izbor metode zasniva na analizi činjenica pri čemu je potrebno sagledati:

- prirodu transakcija koje su predmet analize,

- dostupnost i pouzdanost podataka za anali$\mathrm{zu}$,

- $\quad$ stepen uporedivosti između transakcija obavljenih po transfernim cenama sa transakcijama koje se obavljaju sa ili između nepovezanih lica kada se ove transakcije koriste za proveru usklađenosti transfernih cena obveznika sa cenama utvrđenim po principu „van dohvata ruke“,

- primerenost korišćenja finansijskih podataka nepovezanih lica za analizu usklađenosti transfernih cena po pojedinim vrstama transakcija koje obveznik obavlja sa povezanim licima,

- $\quad$ prirodu i pouzdanost pretpostavki.

Sagledivo je da COVID-19 ima upliv na veliki broj stavki koje opredeljuju metode za dokazivanje transfernih cena. Sa druge strane svaka od metoda za dokazivanje transfernih cena na različit način ukazuje na to da se dosadašnji načini primene metoda moraju prilagoditi novoj okolnosti.

Ekonomske okolnosti su svakako faktor koji određuje uporedivost o čemu govore smernice OECD u paragrafima 1.110 do 1.113 (paragrafi su citirani u skladu sa smernicama OECD iz 2017. godine, treba imati u vidu da je poslednji dostupan prevod na srpski jezik iz 2010. godine, tako da referenciranje može biti različito). „Ekonomske okolnosti koje mogu biti relevantne za utvrđivanje tržišne uporedivosti uključuju geografsku lokaciju, veličinu tržišta, nivo konkurencije na tržištu i relativne konkurentske pozicije kupaca i prodavaca, dostupnost (a time i rizik) supstituta dobara i usluga, nivo ponude i tražnje na celokupnom tržištu, kao i u određenim regionima, ako su relevantna; kupovna moć potrošača, priroda i domet državnog regulisanja tržišta, cene proizvodnje, uključujući cenu zemljišta, rada i kapitala; transportni troškovi, nivo tržišta (na primer preprodaja i veleprodaja), datum i vreme transakcija itd... Postojanje ciklusa (ekonomskog, poslovnog ili proizvodnog) jedna je od ekonomskih okolnosti koje mogu uticati na uporedivost... Geografsko tržište je još jedna ekonomska okolnost koja utiče na uporedivost. Za znatan broj delatnosti, može se ispostaviti da velika regionalna tržišta koja obuhvataju više od jedne zemlje mogu da budu dovoljno homogena, dok su za druge delatnosti, razlike među domaćim tržištima (ili čak unutar domaćih tržišta) vrlo očigledne."

Čak i samo jedna godina u kojoj se ispoljava ekonomska kriza može imati značajan uticaj na pokazatelje poslovanja. Ovu tvrdnju veoma ilustrativno može da nam pokaže i poslednja poslovna kriza koja se dogodila 2008. odnosno 2009. godine. Flagrantan primer su pokazatelji poslovnih subjekata iz automobilske industrije iz Evrope, ali i iz Severne Amerike. Njihove poslovne performanse $u$ godinama pogođenim krizom su značajno lošije nego u godinama pre i nakon krize:

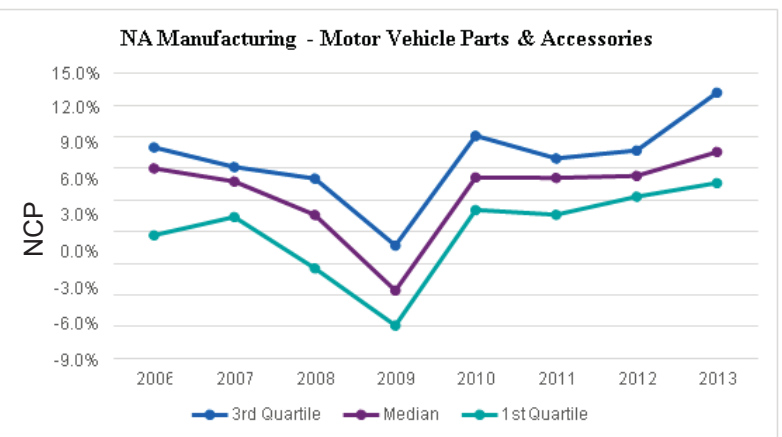

Slika 4 - Severnoamerički proizvođači delova $i$ opreme za motorna vozila

Figure 4 - North American producers of parts and equipment for motorvehicles

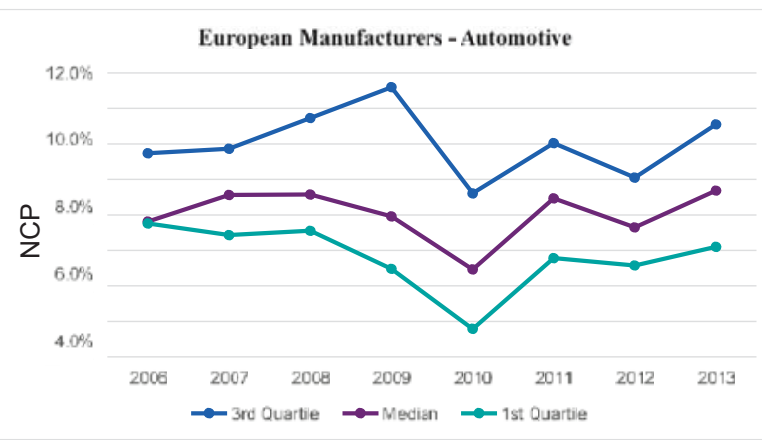

Slika 5 - Evropski proizvođači automobila Figure 5 - European procucers of cars

NCP - Net control point / kontrolna veličina Izvor / Source: COVID-19 and Transfer Pricing Policy: A Lookback Analysis of Routine Returns

\section{Finansijska podrška između povezanih lica}

Pomenuti negativan uticaj COVID-19 jeste i ugrožavanje likvidnosti privrednih subjekata. Tada je neophodno da oni posegnu za dodatnim izvorima finansiranja (Karajović et al., 2020a). Za očekivati je da bi najjeftinija i najbrža podrška u procesu finansiranja mogla da dođe od strane matičnog i povezanih lica. Sa druge strane, iz vizure posmatranja fiskusa, takve transakcije se ne mogu kvalifikovati da su u skladu sa principom "van dohvata ruke“. Regulatorni akti, a naročito Pravilnik o kamatnim stopama za koje se smatra da su u skladu sa principom „van dohvata ruke“ nisu doživeli izmene tako da ova regulativa ne podržava grupu povezanih lica da pruži beskamatnu finansijsku podršku ugro- 
ženim entitetima, jer davaoci sredstava moraju da plate porez na makar i neiskazani prihod od kamate, ali sa druge strane ohrabruje odluku da društva koja su spremna da svoja slobodna sredstva povezanim licima to urade dokapitalizacijom čime bi dokazale svoj odnos dobrog domaćina i privrednika i ne bi imali obavezu plaćanja dodatnih poreskih obaveza.

\subsection{Uticaj pandemije na determinante} međunarodnog kretanja kapitala /

The impact of a pandemic on the determinants of international capital movements

Shodno dosadašnjim objavljenim radovima važila je jedna hipoteza koju i nije bilo potrebno posebno dokazivati, a to je da kapital ne poznaje granice u potrazi za što većim profitom. Zbog neravnomernosti u razvoju pojedinih zemalja, javljaju se razlike u visini profitnih stopa, pa kapital odlazi u one zemlje gde je ona viša.

Multinacionalne kompanije, po pravilu, odlaze iz zemlje osnivanja da bi koristile jeftiniju radnu snagu, ali odlaze i u druge razvijene zemlje da bi kompletirale i osamostalile proizvodni proces, proširile tržište i koristile prednosti ekonomiju obima, da bi istisle konkurente, zaobišle carinske barijere i slično.

Do međunarodne specijalizacije i spoljnotrgovinskih poslova dolazi zbog toga što između pojedinih zemalja postoje razlike u snabdevenosti faktorima proizvodnje. Cene faktora proizvodnje u pojedinim zemljama su različite zbog razlika u snabdevenosti: u nerazvijenoj zemlji radna snaga je jeftina, a kapital skup, dok je u razvijenoj zemlji kapital jeftin, a radna snaga skupa. Zahvaljujući specijalizaciji i spoljnog trgovini dolazi do ujednačavanja cena faktora proizvodnje u pojedinim zemljama i smanjuje se značaj postojećih razlika u snabdevenosti tim faktorima.

Dakle, mogli bismo da kažemo da su tradicionalni motivi međunarodnog kretanja, odnosno izvoza kapitala sledeći:

- Osnovni cilj je ostvarenje većeg profita,

- Jeftinija radna snaga,

- Niže cene sirovina,

- Želja i/ili potreba da se kompletira proizvodni proces,

- Da bi se proširilo tržište za prodaju svojih proizvoda,

- Želja da se obezbedi politični uticaj.

Ukoliko pokušamo sa vremenske distance da sagledamo ove konvencionalno date motive, možemo reći da je već krajem dvadesetog veka moglo u njih da se posumnja. Svedoci smo da se je u februaru 2021. godine ponovo postao aktuelan spor između Evropske Unije i kompanije Apple, takozvani Apple case. lako je u julu prethodne godine Gene- ralni Sud EU presudio u korist Apple u sporu vrednom 15 milijardi dolara po osnovu poreske obaveze, ovaj slučaj je još jednom u žiži interesovanja, jer od njega mogu zavisiti okidači za kretanje kapitala između zemalja u budućnosti. Dakle ni jedan od pobrojanih šest tradicionalnih motiva zasigurno nije bio presudan za Apple da otvori svoj entitet u Irskoj. To je svakako bio razlog poreske optimizacije koja je postignuta zahvaljujući heterogenost poreskih propisa između država u svetu.

Pored ovog novog motiva koji utiče na paradigmu kretanja investiranja, najnovija pandemija jedan drugi motiv stavlja na prvo mesto, a to je sigurnost i dostupnost. U novim okolnostima na sceni na kojoj su zbog pandemije virusa narušeni kanali distribucije i lanci snabdevanja, kompanije posredno ruše ideju globalizma i širenje ne nastavljaju prema destinacijama gde će maksimizirati profit, već počinju da funkcionišu regionalno i lokalno, odričući se više profitne stope, kompanije su prigrlile sigurnost kao najjači motiv za investiranje. Bez obzira na cenu proizvodnih inputa, kompanije iz npr. Nemačke neće računati na jeftinu sirovinu iz Kine, već je radije nabavljaju u svom regionu. Za slučaj pandemije i zatvaranja granica, očekivani visoki profit bi nestao, proizvodnja bi stala i gubici bi i bili značajno veći od propuštene dobiti u saradnji na regionalnoj osnovi.

\section{ZAKLJUČAK / CONCLUSION}

Uticaj pandemije se pokazao kao sveprožimajući na naše živote, ponašanje $i$ poslovanje. $U$ novonastalim okolnostima ponašanje privrednih subjekata nije isto kao i u dosadašnjim uslovima privređivanja. lako su neke od posledica pandemije COVID-19 kratkoročne, za međunarodnu trgovinu nova paradigma je ozbiljna promena i ponekad se čini da je ovo okolnost kojom se ne može upravljati. U dugoročnom vremenskom okviru, potencijalni uticaj pandemije može biti dublji nego što se to predviđalo, što će dovesti do strukturnih promena u procesu ekonomske globalizacije. Pandemija može intenzivirati postojeće tendencije država da se okrenu ka sebi i da se takmiče otvorenije za ekonomsku i političku dominaciju u svetu. Što je veći uticaj pandemije, veće su šanse da ćemo videti intenzivnije promene paradigme u međunarodnim trgovinskim odnosima i upravljanju.

\section{LITERATURA / REFERENCES}

[1] COVID-19 and international trade: Issues and actions, dostupno na http://www.oecd.org/coronavirus/policyresponses/covid-19-and-international-tradeissues-and-actions-494da2fa/ 
[2] COVID-19 and Transfer Pricing Policy: A Lookback Analysis of Routine Returns, dostupno na: https://assets.kpmg/content/dam/kpmg/us/pdf/20 20/06/tnf-tp-wnit-june8-2020.pdf

[3] COVID-19 implications for transfer pricing, dostupno na:

https://www.financierworldwide.com/covid-19implications-for-transfer-pricing\#.X09m48gzZPZ

[4] Evenett, S. (2020), Tackling COVID-19 Together, Global Trade Alert, University of St. Gallen, Switzerland, https://www.globaltradealert.org/ reports, (accessed on 6 April 2020).

[5] Farrell, H., Newman, A. (2020), Will the Coronavirus End Globalization as We Know It?, Foreign Affairs, 16 March 2020. https://fam.ag/2QYcdXg.

[6] Gruszczynski L., (2020), The COVID-19 Pandemic and International Trade: Temporary Turbulence or Paradigm Shift?, European Journal of Risk Regulation, 11(2), 337-342

[7] Jovanović Gavrilović Predrag, (2010), Međunarodno poslovno finansiranje, Ekonomski fakultet, Beograd.

[8] Kaličanin M., Kaličanin Z., Perić M. (2020), Značaj digitalizacije za održivi razvoj u finansijskoj industriji, Ecologica, 27(100), 683-689.

[9] Karajović M, Kaličanin M, Kaličanin Z, (2020a), Uticaj Kovida-19 na izveštavanje o transfernim cenama, Revizor, 23(89-90), 49-60.
[10] Karajović M, Kaličanin M, Kaličanin Z (2020b), Budžetiranje i održivi razvoj, Ecologica, 27(100), 707-713.

[11] Munitlak Ivanović O, Vujić M. (2021), Posledice delovanja Covid-19 na ekonomski sektor i životnu sredinu, Ecologica, 28(101), 118-124.

[12] Pravilnik o transfernim cenama i metodama koje se po principu „van dohvata ruke“ primenjuju kod utvrđivanja cene transakcija među povezanim licima (Službeni glasnik RS, broj 61/2013, 8/2014 i 94/2019)

[13] Privreda, ekonomija i korona virus: Hoće li pandemija poništiti globalizaciju, dostupno na https://www.bbc.com/serbian/lat/svet-652181914

[14] Smernice OECD za primenu pravila o transfernim cenama za multinacionalna preduzeća i poreske uprave (prevod), Srpsko fiskalno društvo, Beograd, 2011

[15] Vassileva A, Simić M, Stevanović M. (2020), Implications of COVID-19 for international business, Ecologica, 27(100), 589-596.

[16] Šiljak V, Zrnzević N, Stefanović R, Perović A, Veselinović J, Đurović D. (2021), Uticaj Covid-19 na budućnost sporta: održivost i obnova, Ecologica, 28(101), 72-81.

[17] Živković D, Petrović P, Ercegović M. (2021), Uticaj pandemije na ekonomski razvoj: tercijalne delatnosti, Ecologica, 28(101), 99-104. 